\title{
Share Prices, Performance Information of Financial Statements and Shareholders' Investment Decisions
}

\section{Onyekachi Silvia Nwakaego}

\author{
Department of Accounting, College of Management Sciences \\ Michael Okpara University of Agriculture, Umudike, Nigeria \\ onyekachi.silvia@mouau.edu.ng
}

Received: 04.04.2020 Accepted: 19.05.2020

Date of Publication: June, 2020

\begin{abstract}
Financial statements, being the representations of the management primarily to the shareholders as their employers are expected to attract a reaction in line with the proprietary theoretical framework. This study was borne out of the quest to assess the reliance of the common stockholders on the financial statement information with respect to profitability and stock prices in their investment decisions. Ten money deposit banks in Nigeria were studied using the expost facto research design and multiple regression analytical technique. The results showed that shareholders' investment decisions in banks rely considerably on stock prices information and financial statement information on profitability with respect to returns on assets at the lag length of one year. It was therefore concluded that financial statements, in practical terms, remain the guide for investors in their quest to see what transpires within organizations; and information on stock prices are also relevant to investment decisions since they complement opinions on the financial statements. Hence, the study recommended that organizations' management, policymakers, governments and accounting bodies at large should treat the issues bothering on financial reporting with all sense of importance since they are capable of influencing economic decisions and their influence on the capital market is certain.
\end{abstract}

Keywords: Financial statements, share prices, shareholders, investment decisions

\section{Introduction}

The preparation and publication of financial statements stem from the core stewardship duty of the directors of a company to account for their performance over a period to the entire stakeholders and especially the shareholders who they represent; and to also present a statement on the status of the firm's affairs at a given date. So the essence of preparing the financial report by the directors is for them to lay claims on the extent of their performance and present the financial position of the firm to its shareholders. It then follows that, if directors communicate facts about the 
company through the financial statement, then investors must necessarily base their judgments and decisions about a company on the strength of the information contained on its financial statement especially when these statements have been audited and given a 'clean bill' report.

Financial statements are sets of individual economic reports which provides information on the performance and status of any organization. It is a method of communicating to the business owners, information on the resource obligations and performances of the stewards of the business. According to ICAN (2013) the objectives of financial statements are to provide information about the performance, financial position and consequently changes in the financial position of any enterprise for the essence of assisting a wide spectrum of financial information users in making economic decisions. The importance of financial statement lies on the information contained in it and the consequent decisions and actions of various users based on them. Hence many countries of the world place stringent rules and detailed procedures for firms to adhere to, before publishing their financial statements especially registered companies. These rules usually bother on the contents, procedures, format, layout and auditing of financial reports. In Nigeria, under the regulation of the Financial Reporting Council of Nigeria FRCN, companies are to prepare Income Statement, Statement of financial position or balance sheet, Statement of changes in equity, cash flow statement amongst others. All these are targeted at enhancing financial reporting and encouraging its use for investment decisions.

Investment decision can be a very crucial event requiring huge amount of financial commitment and payback time frame; and so demands proper and accurate information for detailed analysis of competing options and consequent selection. It is a known fact that published financial information as contained in a firm's financial report is capable of having effects on the future outlook of the firm as it has the tendency of rolling out different activities from different stakeholders of the firm, it is essential for the financial report to represent the true picture of claims made by the organization. On the wider scope, the credibility of published financial statements is even paramount to the success of any capital market (Ihendinihu and Robert, 2014). The importance and authenticity of information in the financial statements of any organization goes a long way in determining the how its stakeholders react to it. Osuala, Ugwumba and Osuji (2012) submit that when the financial statements of any organization presents information that are far better or worse than what is expected, then there is a tendency for its stock prices to go up or down in the market. Popoola, Akinsanya, Babarinde \& Farinde (2014) also posits that investors contemplate about their investment decisions in any firm based on information presented in the financial statements.

However, there are also indications that investors in Nigeria may not have the culture of consulting with financial 
reports of organizations prior to their investment decisions as anticipated. Sequel to the recent corporate failures and financial scandals which has befallen the corporate world both at international and national scenes, investors may have good reasons for not utilizing the contents of financial statement as a basis for their investment decisions. Osuala, Ugwumba and Osuji (2012) state that shareholders of corporate firms do not appear to give proper attention to the contents of financial statements while making investment decisions but will rather take cognizance of other extraneous variable such as market price of shares, frequency and consistency of dividend payments.

In spite of the above possibility, it is evident that companies incur expenses of considerable magnitude annually in preparing, auditing and publishing both soft and hard copies of their financial statements with the inclusion of the cost of circulating them to all the shareholders. So the justification of costs incurred in publishing financial reports lies heavily on their usefulness for investment and other decisionmaking purposes.

Hence this paper purposes to study the effects of financial statement contents on profitability and market prices of shares on shareholders' investment decision-making in Nigeria.

\section{Objective}

This study intends to appraise the effects of financial statement information contents and market prices of shares on investment decisions of shareholders of some selected banks in Nigeria. However, the study will specifically pursue the following objective:

i. Assess the effect of returns on assets as financial statement information on the investment decisions of shareholders.

ii. Assess the effect of earnings per share as financial statement information on the investment decisions of shareholders

iii. Analyse the influence of market price of shares on the investment decisions of shareholders.

\section{Hypotheses}

The study, in pursuance of the above stated specific objectives therefore hypothesizes as follows:

Ho1: Returns on assets has no significant effect on the investment decisions of shareholders

Ho2: Earnings per share have no significant influence on shareholders' investment decisions

Ho3: Market price per share has no significant effect on shareholders' investment decisions of some selected money deposit banks in Nigeria.

\section{Literature Review \\ Conceptual Review}

Financial statement can be described as the report of the firm in which it puts up claims of its financial performance, wealth created, distribution, financial position and changes in financial position and explanatory notes to guide understanding of the statement. Ojiuko (2001) defined financial statement as a collection of data organized to reflect a logical and consistent accounting procedures aimed at conveying understanding of some financial aspects of a business firm. Ekwe (2013),

\section{URL: http://journals.covenantuniversity.edu.ng/index.php/cjbss}


described published financial statement as the audited annual report and accounts of an organization for the period represented; the financial statement comprising of an income statement, balance sheet and the cash flow statement. In Nigeria, public companies are required by the law to publish their financial statements annually and also to send them out to shareholders before the day of the annual general meeting so as to protect the right of those investors. The authenticity of the claims of any organization's directors in a financial statement is very critical to the effectiveness of the investment decisions of various stakeholders who rely on them for their investment decisions, hence the Company and Allied Matters Act is a legislative effort by the Nigerian government to regulate the credibility of financial statements in the economy. To further ensure the credibility of published financial statement, Ekwe (2013) maintained that it must be endorsed by a reputable audit firm. The above assertion implies that investors will accept or rely on published financial statement based on how much confidence they have on the auditor who had expressed an unqualified opinion on such financial statement. Some of the qualities of financial statement content which will also influence the credibility of a financial statement and by extension its acceptability includes relevance, reliability, timeliness, consistency, understandability, objectivity and comparability.

However, recent developments on corporate failures and its close affinity with accounting scandals may have eroded the confidence which investors had hitherto vested on audited and published financial statement. This is the major issue that led to loss of confidence and wide agreement by some scholars that financial statement may not be useful for investment decisions of potential shareholders after all. Ekwe (2013) also noted some problems associated with published financial statements to include subjectivity in the measurement process of some financial statement items, inability of the financial statement to show some non-monetary factors that affect financial condition, complexity and technicality of reported information in the financial statement, and creative accounting. Creative accounting has to with the manipulation of financial statement information within the auspices of legal and other regulation but such that it doesn't portray the true and fair view of the company's financial performance and status.

In theory, it is believed that financial statements should serve as a roadmap to anyone who must access the path of the performance or status of any organization. This is because the contents of a financial statement when reduced to ratios and compared against other firms or previous performances of the same firm indicates how favourable the firm has been doing or otherwise. Hence investors use its contents for proper analysis in their decisions to acquire more investments in the organization or sell off their stake and also, potential investors who are speculating in the market are believed to analyze financial statement while 
deciding on which company to invest in. Bankers, financial advisers and consultants, government bodies, creditors, lenders and a host of other stakeholders of the company base their decisions on the claims of the financial statement.

\section{Financial Statement Information}

The functions of accounting are to measure the activities of the company as well as communicate and interpret those measurements to people; this is achieved through the preparation of financial statement.

.According to Duru (2012), financial statement is a statement which conveys to management and to interested outsiders a concise picture of the profitability and financial position of a business. It is therefore expected that a financial statement of any company should give a stewardship report of the dealings of the management team in collaboration of other employees with the financial resources of the investors who are the owners of the business.

Financial statement information therefore comprises of all information which can be obtained from the financial statement and are utilized for reaching final investment decisions. Shareholders need to receive full benefit of their investment and so need clear and fairly stated information to enable them make effective and efficient investment decision and such information are expected to be fully contained in the financial statements of the companies of interest to the shareholders (Osuala, Ugwumba and Osuji; 2012). An average investor will be interested in the profitability, growth, leverage and efficiency of the entity where he has invested his resources hence information regarding these factors which are contained in the financial statement become his foci points.

\section{Qualities of Financial Statement}

The provisions of International Accounting Standards Board (IASB) on the qualitative characteristics of financial statements include:

i. Relevance and faithful representation: these are regarded as the fundamental qualitative characteristics which connote neutrality, completeness and freedom from error. Relevant financial information suggests that such information is capable of making a difference to the end decision of the financial statement user. Relevance of financial information is also related to materiality i.e. the weight of financial information that makes it relevant to the decision making process of its user. Financial information is adjudged as material where its omission from the financial statement is capable of influencing economic decision of the users. Also the financial statement should show a consistent and true representation of all the matters it purports to represent.

ii. Comparability, Timeliness, Verifiability and Understandability: these are enhancing qualitative characteristics that make financial reports more useful for economic decision making. Comparability entails the preparation of financial information contents in a report in such a manner that makes the user

URL: http://journals.covenantuniversity.edu.ng/index.php/cjbss 
able to compare similar information of a given firm against other firm within the industry or against the report of the same firm of other accounting years. But the timeliness refers to the provision of these information at a time it will influence and inform their decision when it has not become a stale information. Verifiability suggests that various independent and knowledgeable parties are capable of reaching a consensus on the authenticity of the information content of the financial statement. Understandability on the other hand involves classifying, characterizing and presenting financial information clearly and concisely such that users who are expected to be people with basic financial knowledge can understand the information contained in the financial statement (Entop 2016).

\section{Contents of Financial Statement}

\section{Profitability and Performance Information}

Information on profitability of a business is of utmost interest as no rational investor will want to commit to a business that is not making profits. William (2012) submits that profitability is the best measure of a business' performance. The essence of most business ventures is to make returns to their owners; so it is fundamental to the existence of the business that they make profit and information on a business' profitability is also fundamental to the decisions of an investor who is the proprietor. However there are certain accounting information contained in the financial statement or computed with financial information available in the financial statement in order to measure the profitability of any business firm. The net profit of a firm shows the level of profit attained by a company each year after the administrative costs and other costs of operation have been deducted from gross profit. But a better view of profitability will entail relating the net profit to an accounting information item that shows evidence of resource investments in the firm. According to Anaja and Onoja (2015) common profitability measures compare profits with sales, assets, equity and liabilities: net profit margin, return on assets, and return on equity. Thus some of the measures of performance and profitability used in assessment or comparison of firms include; Returns on Equity, Returns on Capital Employed, Returns on Assets, Gross profit margin, etc. information on profitability can be accessed through the statement of comprehensive income or income statement.

\section{Liquidity Information}

In as much as businesses are making profits, their continuity in the business is not guaranteed in the absence of strategic liquidity plans and positioning. Liquidity in this context denotes raw cash and near cash resources that are applied in the operations of the business and in the settlement of financial obligations as they fall due. Chordia, Sarkar and Subrahmayam (2005) stated that "liquidity is the ability of a company to sell large quantity of assets at a reasonable price to meet its short term financial obligations". It is another 
area of interest to an average investor given that the future profitability of the investor is threatened in the face of liquidity problems. Some of the measures of liquidity positions of businesses are computed with financial information obtained from the balance sheet such as current ratio and acid test ratio. Another way to evaluate the flow of financial resources in a firm is through the cash flow statement which shows the sources and application of funds by the organization. According to Patrick, Nach, Epstein \& Budak (2002), cash flow statements helps the investors and creditors to access the ability of the firm to generate positive future cash flow, ability to meet the debt obligations and to shed light on the cash and noncash aspect of the investing and financial transactions.

\section{Leverage Information}

Information on the leverage credibility of a company boosts the confidence of both creditors and investors on the sufficiency of proprietors' investment in the firm and as such affirming the ability of the company to cover their liability in the case of winding up. This is usually very important to even potential investors and so it is an area of concern to management of companies. The test of a companies' leverage is usually computed using the total debt to equity ratio and long term debt to equity ratio; they are expressed respectively as total debt or long term debt divided by total equity. According to Woo \& Baker (2005) percentage of the long term debts for a unit of shareholders equity is revealed by the long term debt to equity ratio; this serves as a measure of a firm's leverage.
Financial Statement and Investment

\section{Decision}

Investment decision simply refers to the choice of where, how and magnitude of financial resources to commit to a particular venture by an investor after a careful analysis of alternative options (Virlics; 2013). It is a decision on the commitment of individual or firm's financial resources on long term assets (Bamidele, Ibarahim \& Omole; 2018). This is often called economic decision taken by existing and potential investors and lenders on the basis of the financial statement of any given organization. According to Entop (2016), the IASB elaborated investment decisions of firms to include the following:

- Decision on when to buy, when to keep and when to sell shares of their capital;

- Assessment of the management skills or responsibility of the management;

- Assessment of the entity's ability to remunerate the staff and to offer other benefits to its employees;

- Assessment of the security that the entity is able to provide for the loans it was granted;

- Determining tax-related policies;

- Determining the profit and dividends to be distributed;

- Provision and use of statistical data on the national income;

- Regulation of company business.

Nkuhi (2015) posits that investment decisions of firms are generally known as the capital budgeting decision and may be defined as the firm's decision to invest its current funds most efficiently in the long-term assets in anticipation of an expected flow of benefits over the

URL: http://journals.covenantuniversity.edu.ng/index.php/cjbss 
years. These assets may be fixed assets. However companies and individuals do invest in shares and other securities and at such times, the use of financial statements of their choice organizations to make analysis and arrive at final selection of the best alternative become pertinent. According to Osuala et al (2012) shareholders of a company, both existing and potential, will want to know how effectively the directors are performing their stewardship function. They will use the financial statement as a basis for decisions to dispose of some or all of their shares, or to buy some more. Investment decisions depend on expectations of the benefits of the investment, which in turn depend on expectations of future growth and product demand. Expectations of future growth are based on information that includes earnings per share, dividends per share, leverage, and liquidity. Thus, the financial statements are considered very important to shareholders.

\section{Financial Statement Information and Investment Decisions}

Most reviewed empirical works that were carried out in the area of financial statements information and shareholders revealed that researchers found a plausible association to exist between financial information and investment decisions of shareholders (Nkuhi 2015; Heikal,Khaddafi \& Ummah 2014; Zagger \& Zagger 2006; Anaja \& Onoja 2015; Ekwe 2013). These opinions were theoretically anchored on the traditional role of accounting which bothers on the provision of historical information as it relates the business performance and further usage of the past performance so detected to measure or estimate the future and form opinion about the firm's future performance. It is therefore important and proper that financial statements being crucial to investment decisions are regulated by different national bodies and globally by IASB in order to forestall uninformed decisions.

\section{Stock Prices and Shareholders' Investment Decisions}

Osuala, Ugwumba and Osuji (2012) submitted that shareholders in the Nigerian capital market cannot be said to have relied on the information available in the financial statements to make decisions as regards their investments based on the findings they made in their empirical study. The result hence appears to differ from opinions held by most researchers on this topic. The researchers opined that market price of shares is one of the vital factors capable of influencing the shareholders' decisions asides financial statement information.

Information on stock prices is not contained in financial statements produced by companies in Nigeria. Rather these information are gotten from the business news and reports circulated by the Nigerian Stock Exchange and Securities and Exchange Commission. Stock prices can be described as the market price of common stocks held by ordinary shareholders. Market prices of ordinary shares are usually higher than their book values often representing the extent to which shares have appreciated in value in the market as against as the book worth of the shares. Stock prices change in stock markets on a daily basis. Moreover, during certain times of the year, it is easy to notice that stock prices 
appreciate every morning, and this may take place many times in one day for some stocks. This means that stock prices are determined by supply and demand forces influenced by corporate firm characteristics. There is no full proof system that indicates the exact movement of stock prices. However, the factors behind increases or decreases in the demand and/or supply of a particular stock could include company fundamentals, external factors, and market behavior.

It is possible that, in addition to financial statement information, shareholders may consider the growth or behavioral pattern of stock prices of common stock prior to their investment decisions as opined by Osuala, Ugwumba and Osuji (2012).

\section{Theoretical Review}

Certain schools of thought abound on the nature of information which should be central to the preparation of financial statements including which group of people that should be borne in mind when preparing the financial reports of organizations. These theories are regarded as theories of equity and are reviewed hereunder;

Entity Theory: this theory of financial statement upholds the entity concept of accounting. The proponents of entity theory upholds that since an organization is a distinct body having its own existence other than that of its owners; this fact and concept should also be borne in mind when preparing the financial statement. In other words, the business unit rather than the proprietor is the center of accounting interest (Manukriti 2016). And accounting information produced by the organization should be targeted to meet this purpose.

Hence the accounting equation will be: Assets $=$ Liabilities + Shareholders' Equity

Enterprise theory: upholds the social theory of accounting. Enterprise theory conceives firms as organisms that exist for the benefit of various groups of people which will include shareholders, creditors, employees, government and the general public. It holds that financial statement of firms should be prepared in such a way as to show the value added by the firm to these groups of people having in consideration that they are all stakeholders to the business of the organization. As such the retained earnings of the firm and any other reserve made to promote the goingconcern is not solely for the benefit of the shareholders but other stakeholders who are beneficiaries of the value added of the organization.

Evidently from the stance of enterprise theory, the best statement in the financial report that will serve the interest of all the stakeholders is the value added statement. But it is important to note that International Financial Reporting Standards currently do not promote this social theory in the financial report having not included value added statement as mandatory part of financial reports.

Proprietary Theory: the proprietary theory of equity posits that the financial reports should be tailored to meet the needs of contributors of the business capital alone. The concept underpinning this theory is that since the business firm is an agent to the shareholders or 
an arrangement through which they operate; its financial reports should be addressed to these equity holders in the manner that suits their needs.

This theory reflects the traditional role of accounting information dating back to the period of stewardship accounting where the stewards are expected to release information to the use of the masters, i.e. the proprietors and no other. The accounting equation under the proprietary theory will be presented as:Proprietors' Equity = Assets Liabilities.

\section{Under-pinning Theory}

A narrower variant of proprietary theory is the residual equity theory which excludes the preferred stockholders from the equity equation. However, the implication of this theory is that elements of the financial statement which do not address the information requirements of the shareholders may not necessarily be included. It emphasizes the importance of the income statement from which the proprietors can assess the financial performance of the firm and consequently their dividends; the statement of financial position to view the status of assets as against liabilities and networth; cash flow statement to assess their liquidity; and other accompanying parts that explains the statements further. Sharma (2012) holds that Income statement, balance sheet and statement of cash flow are the basic and the most important financial statements which interprets the quantitative data of a company's performance; and the standard of International Accounting Standards Board (IASB) which upheld that firms need only prepare statement of financial position, statement of comprehensive income, other comprehensive income and cash flow statement and other accompanying footnotes of which all geared to meet the needs of the primary users of financial information (where primary users are present and potential investors, lenders and other creditors) alone, suggests that the board adopts this traditional concept of financial statement.

Proprietary theory with emphasis on the residual equity theory is adopted for this research work for its focus on the information needs of shareholders since it is purposed to assess the rate at which investors in the equity shares of firms rely on the financial report and its content in the formation of their investment decisions.

\section{Empirical Review}

The use of financial reports and financial information by investors, existing and potential in the formulation of their investment decisions have attracted the attention of several scholars from different countries of the world.

Zaigham, Wang and Ali (2019) studied the causal relation between stock market performance and firm investment decisions in China. Stock prices were adopted as the independent variable whereas the sampled firms' investment expenditures were adopted as the dependent variable. Using panel regression analysis, the researchers found that stock prices have negative influence on the investment decisions of the managers of the selected firms. They also concluded that firms who face financial challenges tend to have higher

\section{URL: http://journals.covenantuniversity.edu.ng/index.php/cjbss}


sensitive investment decisions in response to changes in stock prices than others who do not. A condition that was attributed to information assymentry.

Berheci (2008) studied the interdependence of the components of financial statements and its influence on financial decisions. The study analyzed financial information needs of various parties to the financial report and considered the financial report an essential commodity in the investors' decision making process. It was concluded that the lack of transparency of the published information, which is subject to evenness and conservatism, is the cause for the information asymmetry between the providers and the users of accounting information. While noting that lack of knowledge on economic matters by users of accounting information can contribute to uninformed decision, the study recommends high quality reference to the system and regular financial reports audit as a panacea to the problem of relying on unfaithful financial reports in making investment decisions.

According to Zager and Zager (2006), significant number of investment information comes from accounting information systems and from financial statements and "reading" contents of financial statements provide whole number of different instruments and analyses procedures for understanding business. After a thorough review of various financial ratios, the researchers concluded that condensed statement and consequent financial information can be very useful in estimating the current business quality and creating assumption for more successful business in the future.

Maidoki (2013) utilized primary data and survey approach to study the interrelationship between financial reports and effective managerial decision making. The concept which forms the backbone of the research rested on the fact that managers often engage in decisions which are made on the basis of their knowledge about financial information contents of the financial statement. The study which was targeted at the staff of WEMA bank plc in western Nigeria applied tables and percentages in the analyses of responses gathered, and they found that financial reporting as a device for disclosure of organization's financial dealings can eliminate some problems, resulting from inappropriate planning and decisions. The study hence concluded that to resolve conflict of incomparability of financial statements of similar firms, entities should comply with rules regulating the preparation and disclosure of financial statement and reports in order to ensure uniformity and accuracy.

Osuala et al (2012) studied the effect of information content of financial statements on the investment decisions of shareholders using a time series data. The coverage of the study on information content of financial statements includes profitability, earning per share, dividend per share, leverage and liquidity whereas shareholders' investment decisions were represented by change in number of shares. The research applied regression analytical technique and found that shareholders in the Nigerian capital

\section{URL: http://journals.covenantuniversity.edu.ng/index.php/cjbss}


market do not rely much on financial statements as a major determining factor for their investment decisions. It was observed that other factors or variables outside firms' annual reports such as regularity of dividend payment and market price of shares are vital to shareholders' investment decisions. The study therefore recommends proper awareness creation by the appropriate agencies to enhance shareholders' understanding of the relevance of published accounts to enable them to know the financial states of the companies of their interest before making investment decisions.

Another study in Tanzania adopted primary data approach to analyse the role of financial statements in investment decision making. The study purposed to examine how financial reports information aid investors to evaluate the performance of a company for investment decision making. The study adopted the use of primary data collection method and targeted respondents that are knowledgeable in ratio analysis as a means of extracting financial information. Its findings show that financial statements are critical in the investment decision making and investors are confident with the use of financial statements in arriving at investments decisions. It was thereby recommended that firms should fully apply the IFRS principles in the preparation of its financial reports and investors should seek consultancy services in the use of financial reports to make investment decisions (Nkuhi; 2015).

Ekwe (2013) conducted an investigation on the degree of reliance of the published financial statements by corporate investors utilizing a survey research design by which data were generated by means of questionnaire administered on one hundred and fifty corporate investors and senior management officials of the selected banks. On the basis of descriptive statistics and $t$ tests which was conducted on SPSS analytical package, the study revealed that investors do understand the financial statement well before making investment decisions; most investors depend heavily on the credibility of auditors/financial expert approval of financial statement in making investment decisions and as such published financial statement is very important in the investors' decision making. The researcher therefore recommended that adequate care and due diligence should be maintained in preparing financial statements to avoid faulty investment decisions which could lead to loss of funds and possible litigations.

Anaja and Onoja (2015) combined both secondary data from ten years' time series and primary data to ascertain the role of financial statement on investment decision making in United Bank for Africa Plc. of Nigeria. The results of analysis showed that investors depend heavily on the credibility of auditors/financial expert approval of financial statement in making investment decisions, and so published financial statement is very important in the investors' decision making. The scholars therefore concluded that, profitability, assets, liabilities and equities of banks are significant ways of evaluating the performance of a banks 
and thus, recommended that adequate care and due diligence should be maintained in preparation of financial statements to avoid faulty investment decisions

\section{Gap in Literature}

Existing literature on the use of financial statements contents in making investment decisions have been approached from primary and secondary data perspectives. And some of the works found through their analyses that financial information contained by the financial statements influence the investment decisions of the ordinary shareholders. However, this is with the exception of Osuala, Ugwumba and Osuji (2012) who maintained in their findings that results of financial performance and status of firms did not affect the investment decisions of common stockholders.

So this research is geared towards following up on this distinctive opinion and also go a step further in including common stock prices of the firms in the regression model with the aim of holding or refuting the claim of the above researchers.

\section{Methodology}

This research adopted the expost facto design which is appropriate for measuring facts and variables which occurred before the research and the variables cannot be manipulated in the research process. The area of study is Nigeria since the companies under study are operating within the Nigeria capital market.

Secondary data were sourced from the annual reports of ten commercial banks in Nigeria using the judgemental sampling technique. The banks covered include Zenith, Diamond, Guaranty Trust, Sterling, Union, First City Monument, United Bank of Africa, Access, Fidelity and Stanbic IBTC. Shareholders' investment decision and financial statement information of these banks relating to profitability, efficiency and market prices of stock were collected. Panel data collected for the firms over a twelve year period (2006 2017) on four focus variables resulted in 480 data points used for the study. Multiple regression analysis was employed for analyzing the data set.

\section{Model specifications}

The comprehensive model for the regression analysis is presented below:

SIDit $=\beta 0+\beta 1$ ROAit $+\beta 2$ MPSit + $\beta 3$ EPSit $+\mu$ it

Where: SID = Dependent Variable

ROA, MPS, EPS = Independent Variables

$\beta 0=$ Intercept.

$\beta 1, \beta 2, \beta 3=$ Parameters for independent variables beta coefficients

Where: SID = Change in Shareholders' Investment Decision i.e. change in number of shares outstanding.

Returns on Total Assets; Profit after tax Total assets

MPS $=$ Market price per Share EPS = Earnings per Share

\section{Results and Discussions}

Data collected from the financial reports of the selected banks were analyzed using the panel regression method while adopting the fixed and random effect model. The Hausman test was conducted to guide the choice of either fixed or random effect models of the multiple regression results obtained. 
This test has a pair of hypotheses which are stated thus;

\section{Hypothesis I}

Ho1: Returns on assets has no significant effect on the investment decisions of shareholders

Ho: Accept the random effect model

H1: Accept the fixed effect model

The result of the Correlated Random Effects - Hausman test appended as Appendix I yields a chi-square value of 14.77 approximately at $1 \%$ level of significance, so we reject the null hypothesis and therefore accept the fixed effect regression model as appropriate for testing the hypotheses raised in this work.

Table 1 below contains the result of the regression estimate coefficient for returns on assets as one of the financial statement information on the shareholders' investment decisions in ten selected commercial banks in Nigeria. According to the result obtained in the table, returns on assets at the lag one year period has a positive association (beta value $=7.72$ approximately) with the changes occurring in the equity holdings of selected banks.

It therefore suggests that returns on assets as a measure of banks' profitability in terms of total assets invested in the banks moves in the same direction with changes occurring in the shareholders' decisions to invest more in the banks or otherwise. It also implies that reduction in the values of returns on assets of selected banks in a given year will, all things being equal, be associated with corresponding decrease in shareholders' investment decisions in the following year and at a statistically significant level.

Table 1: Fixed Effect Regression of ROA, EPS and MPS on SID

Dependent Variable: SID

Method: Panel Least Squares

Date: 11/26/18 Time: 13:47

Sample (adjusted): 20072017

Periods included: 11

Cross-sections included: 10

Total panel (balanced) observations: 110

\begin{tabular}{crrrr}
\hline \hline Variable & Coefficient & Std. Error & t-Statistic & Prob. \\
\hline \hline C & -0.281014 & 0.201497 & -1.394634 & 0.1663 \\
ROA(-1) & 7.718132 & 2.603194 & 2.964870 & 0.0038 \\
EPS(-1) & 0.000571 & 0.002995 & 0.190648 & 0.8492 \\
MPS(-1) & 0.047098 & 0.014005 & 3.363067 & 0.0011 \\
\hline \hline
\end{tabular}

URL: http://journals.covenantuniversity.edu.ng/index.php/cjbss 
Effects Specification

Cross-section fixed (dummy variables)

\begin{tabular}{lrll}
\hline \hline R-squared & 0.503473 & Mean dependent var & 0.448787 \\
Adjusted R-squared & 0.404934 & S.D. dependent var & 1.150670 \\
S.E. of regression & 0.088626 & Akaike info criterion & 3.118303 \\
Sum squared resid & 114.9553 & Schwarz criterion & 3.437451 \\
Log likelihood & -158.5067 & Hannan-Quinn criter. & 3.247751 \\
F-statistic & 2.064891 & Durbin-Watson stat & 2.062146 \\
Prob(F-statistic) & 0.026318 & & \\
\hline \hline
\end{tabular}

\section{Source: Researcher's Eviews Output 2018}

So in the light of this result, we reject the null hypothesis 1 as have been restated in this subsection and therefore conclude that returns on assets has significant influence on the investment decisions of shareholders. This outcome is in agreement with that of Osuala, Ugwumba \& Osuji (2012) who employed ROA as a measure of firms' profitability (PRO) and regression as analytical technique, and found that PRO has significant effect on the shareholders' investment decisions of the selected firms in their study.

\section{Hypothesis II}

Ho2: Earnings per share have no significant influence on shareholders' investment decisions

The second coefficient on table 1 above depicts the result obtained for the regression of earnings per share on the shareholders' investment decision. The beta coefficient of earnings per share at the one year lag suggests that EPS influences shareholders' decisions directly. At such, growth in the earnings per share reported by the firm in its financial reports has the likelihood to generate additional investments from the shareholders. It is evident from the foregoing that shareholders of commercial banks in Nigeria are prone to react to changes in the earnings per share reported by banks in the same direction.

However, the direct relationship that is found between earnings per share and shareholders' investment decisions has a low coefficient value of 0.0006 approximately and is not statistically significant. The implication being that the level of association found in this study to exist between the two variables is negligible and does not warrant statistical conclusions or inferences on its basis. This is because the t-statistics of the EPS beta coefficient is low (0.19 $<2$ ) and its probability value is outside the acceptable bounds of $5 \%$.

Hence the null hypothesis which holds that earnings per share have no significant influence on shareholders' investment decisions will be accepted and its alternative implication jettisoned.

\section{Hypothesis III}

Ho3: Market price per share has no significant effect on shareholders' investment decisions of some selected money deposit banks in Nigeria. 
The market price of shares in the selected money deposit banks yields a positive beta coefficient in the multiple regression result on table 1 above. The regression outcome suggests that market price of shares at the lag of one year period will influence the decision of a shareholder to invest in the selected firms at beta level of $5 \%(0.047)$. The implication of this finding is that a unit increase in the market value of shares in the selected banks can lead to $5 \%$ increase in the investment a shareholder is willing to make in the selected commercial banks in Nigeria. Thus, the study opines, based on this outcome that shareholders of selected banks respond to changes occurring in the market value of shares in arriving at their investment decisions.

The above outcome is statistically significant at $1 \%$ implying that the beta coefficient of MPS can relied upon in drawing of statistical inferences. In the light of the findings made thus far as it concerns the market price of shares, we reject the null hypothesis as restated in this subsection and therefore conclude that market price of shares influences investment decisions of shareholders of some selected banks in Nigeria.

\section{Summary of Discussion}

The regression analysis in table 1 above shows that returns on assets and market prices of firms' shares predict the investment decisions of shareholders in the preceding financial year. In addition to the coefficients and their probability values, the residual statistics of the multiple regression analysis also justifies the validity of the regression estimates. The r-squared value of $50 \%$ suggested that the selected variables in the regression model can explain up to half of the changes that will occur in the investment outcome of shareholders in these selected banks. Also, the fstatistics is significant at 5\% suggesting that the regression model is well fitted and independent variables are sufficient to explain the changes that occur in the shareholders' investment decisions which is the dependent variable. The Durbin-Watson statistics of 2.06 approximately indicates that the regression estimate is reliable to a reasonable extent. So the study found that financial statement information on profitability and prevailing market price of shares have significant effects on shareholders' investment decisions.

\section{Conclusions and Recommendation}

Based on the findings made in the previous section, this paper concludes that information on profitability of a bank which can be found in the financial statements as well as the prevailing market price of common stocks held by shareholders can influence significantly, their investment decisions.

The study therefore recommends that financial statements preparation should be viewed substantially as a means of communicating to shareholders and enabling them to arrive at the best economic decisions; thus firms are better instructed to ensure that no part or process of the financial statement preparation should be trivialized.

Shareholders should however understand that immediate gains do not guarantee future wealth; in other words, the observed reaction at the lag one year period may not be the best decisions with respect to changes in their 
investment choices in the selected banks in this study.

Accounting bodies at the local and international scenes should also tighten their grip on the regulation of valid financial statements by companies by ensuring that auditors of public firms beam their torchlight on the bookkeeping process which is fundamental to the final reports they produce.

\section{References}

Amedu, M. (2014). Role of financial statement in investment decision making: a case study of first bank of Nigerian plc. International Journal of Accounting Information Systems 1(2), 91-105.

Anaja, B. \& Onoja, E.E. (2015). The role of financial statements on investment decision making: a case of United Bank for Africa Plc (2004-2013). European Journal of Business, Economics and Accountancy Vol. 3 (2) pp. $12-37$.

Bamidele, M.M., Ibarahim J. \& Omole, L.I. (2018). Financial reporting quality and its effect on investment decisions by Nigerian deposit money banks. European Journal of Accounting, Auditing anf Finance Research, Vol. 6(4), 23-34

Berheci, M. (2008). The annual reports and financial decisions. Retrieved from https://econpapers.repec.org on 21/08/2018.
The government on the other hand, should realize that the credibility of its capital market depends on the soundness of economic decisions made by shareholders of various public firms, so it should ensure that adequate measures which laid to forestall financial reporting fraud are followed up and reviewed from time to time so as to ensure that the aim is not defeated.

Chordia, T., Sarkar, A. \& Subrahmayam, A. (2005). An emprical analysis of stock and bond market liquidity. The Review of Financial Studies. Vol. 18 (1) pp. 86-129

Duru, A. N. (2012). Elements of financial accounting made easy. Enugu, Nigeria Joglas Production Works Ltd.

Ekwe, M.C. (2013). Reliance on published financial statements and investment decision making in the Nigeria banking sector. European Journal of Accounting Auditing and Finance Research, 1(4), 67-82.

Entop (2016). Presentation of financial statements. Entop Consulting Training Guide - Financial and Management Consultants Publication

Heikal, M., Khaddafi, M. \& Ummah, A. (2014). Influence analysis of return on assets (roa), return on equity (roe), net profit margin (npm), debt to equity ratio (der), and current ratio (cr), against corporate profit growth in automotive in Indonesia stock

URL: http://journals.covenantuniversity.edu.ng/index.php/cjbss 
exchange. International Journal of Academic Research in Business and Social Sciences, 4(12)

ICAN (2013). Strategic financial management. ICAN Pack Study Guide. Retrieved from http://www.ican.org on $26^{\text {th }}$ September 2017.

Ihendinihu, J.U. \&Robert, S.N. (2014). Role of audit education in minimizing audit expectation gap (aeg) in Nigeria. International Journal of Business and Management, Canada: Canadian Centre of Science and Education, 9(2), 204-211.

Maidoki, P. B. (2013). Financial reports and managerial effectiveness in planning and decision-making. Journal of Economics, 4(1), 6973.

Manukriti, N. (2016). Accounting theory: role, levels and methodology. Retrieved from www.accountingnotes.net on 29/11/2018.

Nkuhi, A. H. (2015). The role of financial statements in investment decision making: a case of Tanga Port Authority. Retrieved

fromhttps://www.scholar.mzum be.ac.tz on $28 / 11 / 2018$.

Ojiuko, A. (2001). Financial management. Owerri, Nigeria, Bon Publications.

Osuala, A.E., Ugwumba, E.C. \& Osuji, J.I (2012). Financial statements content and investment decisions - a study of selected firms. JORIND, 10 (2), 165 170.

Patrick, R. D., Nach, R., Epstein, B.J. \& Budak,

S.W.(2002).

Interpretation and Application of Generally Accepted Accounting Principles .New York. John Wiley \& Sons, Inc.

Popoola, C. F., Akinsanya, K., Babarinde, S. B., Farinde, D. A. ( 2014). Published financial statement as a correlate of investment decision among commercial bank stakeholders in Nigeria. International Journal of Social, Management, Economics and Business Engineering, 8 (1).

Sharma, R. (2012). Comparing and analyzing financial statements to make an investment decision; case study of automotive industry. Business Economics and Tourism

Virlics, A. (2013). Investment decision making and risk. Procedia Economics and Finance, 6, 169177

Williams, N.G. (2012). Introduction to investment theory. U.S. Yale University, School of Management, University Printing Press.

Woo, G. K.\& Baker, A. (2005). Ratio analysis for the hospitality industry: a cross sector comparison of financial trends in the lodging, restaurant, airline and amusement sectors. Journal of Hospitality Financial Management. 13 (1), 1-12

Zager, K. \& Zager, L. (2010). The role of financial information in

URL: http://journals.covenantuniversity.edu.ng/index.php/cjbss 
decision making process. Innovative Marketing, 2 (3), 35 -40 .

Zaigham, G.H., Wang, X. \& Ali, H.S. (2019). Causal relation between stock market performance and firm investment in China: Mediating role of information asymmetry. Sage Open Journals https://doi.org/10.1177/2158244 019885146

\section{Appendix}

Hausman Test

Correlated Random Effects - Hausman Test

Equation: Untitled

Test cross-section random effects

\begin{tabular}{lrrr}
\hline \hline Test Summary & $\begin{array}{r}\text { Chi-Sq. } \\
\text { Statistic }\end{array}$ & Chi-Sq. d.f. & Prob. \\
\hline \hline Cross-section random & 14.766653 & 3 & 0.0020 \\
\hline \hline
\end{tabular}

** WARNING: estimated cross-section random effects variance is zero.

Cross-section random effects test comparisons:

\begin{tabular}{ccrcc} 
Variable & Fixed & Random & Var(Diff.) & Prob. \\
\hline \hline ROA(-1) & 7.718132 & 5.229345 & 0.976068 & 0.0118 \\
EPS(-1) & 0.000571 & -0.000145 & 0.000001 & 0.3969 \\
MPS(-1) & 0.047098 & 0.018406 & 0.000080 & 0.0013 \\
\hline
\end{tabular}

Cross-section random effects test equation:

Dependent Variable: SID

Method: Panel Least Squares

Date: 11/26/18 Time: 13:49

Sample (adjusted): 20072017

Periods included: 11

Cross-sections included: 10

Total panel (balanced) observations: 110

\begin{tabular}{crrrr}
\hline \hline Variable & Coefficient & Std. Error & t-Statistic & Prob. \\
\hline \hline C & -0.281014 & 0.201497 & -1.394634 & 0.1663 \\
ROA(-1) & 7.718132 & 2.603194 & 2.964870 & 0.0038 \\
EPS(-1) & 0.000571 & 0.002995 & 0.190648 & 0.8492 \\
MPS(-1) & 0.047098 & 0.014005 & 3.363067 & 0.0011 \\
\hline \hline
\end{tabular}

Effects Specification

URL: http://journals.covenantuniversity.edu.ng/index.php/cjbss 
Cross-section fixed (dummy variables)

\begin{tabular}{lrll}
\hline \hline R-squared & 0.503473 & Mean dependent var & 0.448787 \\
Adjusted R-squared & 0.404934 & S.D. dependent var & 1.150670 \\
S.E. of regression & 0.088626 & Akaike info criterion & 3.118303 \\
Sum squared resid & 114.9553 & Schwarz criterion & 3.437451 \\
Log likelihood & -158.5067 & Hannan-Quinn criter. & 3.247751 \\
F-statistic & 2.064891 & Durbin-Watson stat & 2.062146 \\
Prob(F-statistic) & 0.026318 & & \\
\hline \hline
\end{tabular}

